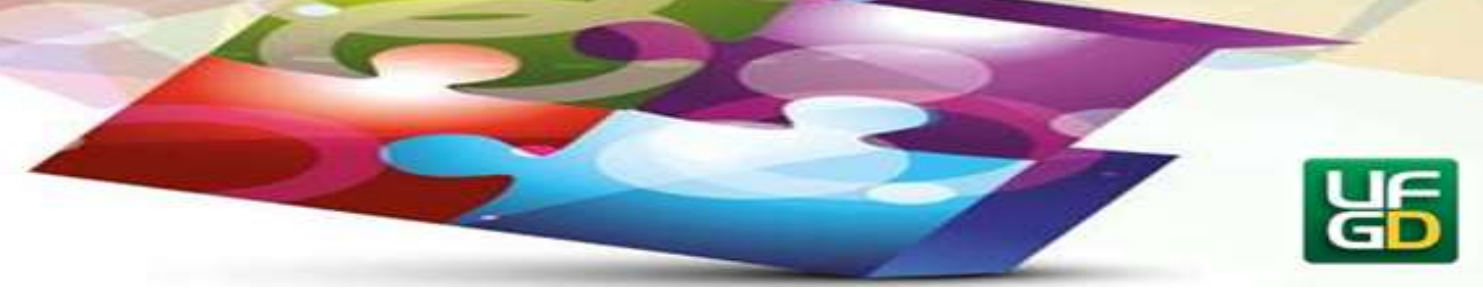

\title{
O TEATRO DA VIDA COTIDIANA
}

THE THEATRE OF EVERYDAY LIFE

\author{
Mitsi Pinheiro de LACERDA ${ }^{1}$ \\ Ludymila Aguiar GEMINO² \\ Lara Silva LEAL $^{3}$
}

Resumo: O artigo estabelece conversações entre algumas orientações advindas da prática teatral e da vida cotidiana objetivando trazer, desde o exercício teatral, movimentos também presentes nas pesquisas em Educação. É no cotidiano que as pessoas vivem e criam sua humanidade, e o exercício teatral pode contribuir para a percepção consciente acerca deste espaço familiar. $\mathrm{O}$ artigo se desenvolve com a defesa do teatro enquanto prática que possibilita a percepção da alteridade, aproximando-se da relação entre artista e público, e da arte que se faz no interior desta relação. Estas discussões pretendem contribuir para com os estudos do cotidiano, as pesquisas em ciências humanas e as práticas de ensino.

Palavras-chave: Teatro. Pesquisa. Vida Cotidiana.

Abstract: The essay establishes conversations between some orientations derived from theatrical practice and everyday life bringing from the theatrical exercise, movements also present in Education. It is in everyday life that people live and create their humanity, and the theatrical exercise can contribute to the conscious perception about this family space. The article develops with the defense of theater as a practice that enables the perception of otherness, approaching the relationship between artist and audience, and the art that in this relationship. These discussions aim to contribute to everyday studies, research in human sciences and teaching practices.

Keywords: Theatre. Search. Everyday Life.

\section{Abrindo as cortinas}

Este artigo, de natureza ensaística, tem como intenção estabelecer conversações entre a vida cotidiana e algumas orientações advindas da prática teatral. Direcionamos as reflexões à

\footnotetext{
${ }^{1}$ Professora do Departamento de Ciências Humanas e do Programa de Pós-Graduação em Ensino da Universidade Federal Fluminense (UFF).

2 Mestre em Ensino pela UFF. Professora do Sistema de Ensino Contemporâneo - SEC - Fundação Cecierj/Consórcio Cederj - Polo Miracema/RJ.

${ }^{3}$ Mestre em Ensino pela UFF. Professora da Escola Municipal Silvestre Mercante - Miracema/RJ.
} 
compreensão do desenvolvimento da pesquisa e do ensino. O exercício teatral que acontece nos palcos e nos cotidianos fornece elementos para provocar o leitor a pensar, "por detrás das cortinas", a respeito de práticas investigativas e suas relações de ensino. Nessa direção, buscamos interlocução junto a procedimentos recorrentes nesta expressão artística, de forma a nos aproximarmos da vida cotidiana. É no cotidiano que todos nós vivemos, criamos e sentimos plenamente nossa humanidade, e o exercício teatral pode contribuir para que nossa percepção acerca deste espaço familiar, se desdobre. A ideia é, humildemente, tentar trazer as lentes que os artistas empregam para observar a realidade, lentes que provavelmente permitem compreender o dia a dia como algo que não se limita à suposta repetição inócua do mesmo.

As interfaces entre arte e vida cotidiana, e entre atividade científica e atividade teatral, estarão presentes no decorrer do texto. Transitando por movimentos empreendidos em cotidianos, as autoras buscam, desobedientemente, dialogar por campos tornados estanques pela lógica da especialização, produzida pela modernidade. Desde que os princípios da racionalidade científica moderna delimitaram seus objetos de estudo e circunscreveram os campos no interior dos quais cada abordagem deveria ser empreendida, a diversidade temática do mundo foi dividida, separada, purificada e trancafiada. Junto a Boaventura Santos, entendemos que a "fragmentação pós-moderna não é disciplinar e sim temática. Os temas são galerias por onde os conhecimentos progridem ao encontro uns dos outros" (1987, p. 48). Transitando pela atividade científica que toma a vida cotidiana enquanto espaçotempo a ser trilhado, buscamos em nossa aderência à prática teatral, a interlocução necessária. Isso porque entendemos nossa atividade científica enquanto

[...] assumidamente analógica que conhece o que conhece pior através do que conhece melhor. Já mencionei a analogia textual e julgo que tanto a analogia lúdica como a analogia dramática, como ainda a analogia biográfica, figurarão entre as categorias matriciais do paradigma emergente: o mundo, que hoje é natural ou social e amanhã será ambos, visto como um texto, como um jogo, como um palco ou ainda como uma autobiografia (SANTOS, 1987, p. 45).

A opção preferencial pela escrita que transita por diferentes campos através de analogias pouco prováveis, é algo que afeta a prática docente. Enquanto alguns adeptos da 


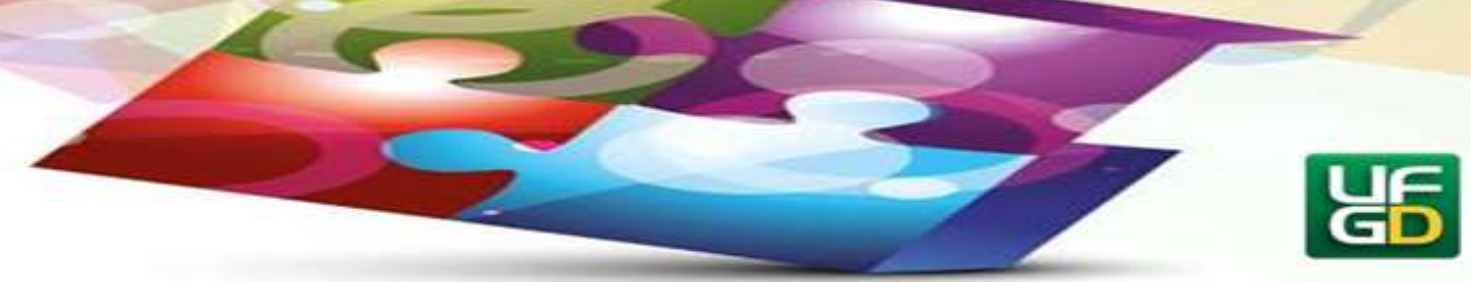

interdisciplinaridade defendem que é preciso aproximar as disciplinas, entendemos que esta importante aproximação não se realiza tão somente pela justaposição de teorias e métodos, mas na conversação transversal que nós, seres humanos, inventamos através das diferentes linguagens e da vida enquanto palco gigantesco desde o qual são reproduzidas as relações sociais de produção (LEFEBVRE,1991a).

De forma a apresentar a entonação oferecida a este artigo, buscamos Henri Lefebvre (1991) que, mergulhando em uma realidade aparentemente simples, aproxima-se do trabalho de Charles Chaplin, observando uma de suas obras, "O vagabundo 4 ". O filme narra a história de um personagem oprimido e desprovido que, desde a margem que habita, dispõe de percepção crítica do mundo, e sobre ele, age. Mostrando-se como vagabundo para os outros, ele toma para si este lugar da exclusão, pois, sem ser notado, vive intensamente uma vida fundada na criticidade e afetividade. Para Lefebvre (1991), as contorções e graças de Chaplin, que levam todos a rir, dizem muito mais do que um olhar desavisado poderia perceber. O segredo estaria presente não somente no corpo do ator, mas na relação que ele estabelece entre sua corporeidade e o mundo. Lefebvre (1991) vê, na expressão artística de Chaplin, a inserção de um estranho em um mundo familiar, e isso nos deixa desorientados diante da subtração da familiaridade. $\mathrm{O}$ que é familiar nos agrada, e também nos oprime.

Veja: andar pelas ruas, sentar na praça, ir à escola são práticas cotidianas que vivenciamos, em grande parte, segundo modelos e referenciais fixados, e pouco questionados. No filme, segundo Lefebvre (1991), o palhaço captura e mostra o que seria nossa atitude em relação àquilo que tem sido considerado trivial e comum, desvelando a grandiosidade contida na vida cotidiana. Astuciosamente incluso na sociedade, o palhaço usa a fantasia e a comicidade para realizar sua crítica social. Inocente à superfície, as cenas cômicas dizem mais do que os tombos, caretas e piruetas podem aparentar. Táticas do fraco no campo dominado pelo forte (CERTEAU, 1994), o palhaço desvela a linguagem do poder, sem que notem sua fuga do lugar marginal que (supostamente) o circunscreve.

\footnotetext{
${ }^{4}$ Originalmente intitulado "The Tramp", com direção de Charles Chaplin, EUA, 1915, P\&B, 32 min.
} 


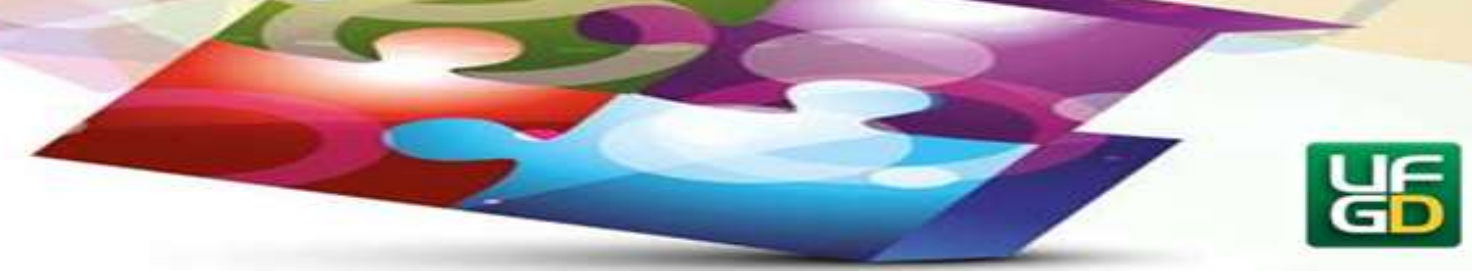

Assim como o palhaço, há aproximadamente duzentos anos, a ocupação dos pintores que retratavam cenários e personagens da vida cotidiana, também não era legitimada. Em algumas ocasiões, os pintores eram proibidos de assinar suas próprias obras, já que sua expressão artística não era considerada. Porém, renitentes e observadores críticos da realidade social, não apenas assinavam suas obras retratando um dos personagens com sua própria face, mas, também inscreviam sua crítica de forma ambígua, preservada por cenas cotidianas comuns. Lefebvre (1991) ajuda a pensar sobre isso quando afirma que o fato de vivermos em ambientes que nos parecem familiares, nos faz acreditar que conhecemos "tudo". Parece que pintores e palhaços perceberam que poderiam desvelar esta familiaridade desde seu interior, tecendo linguagens pictóricas e corporais que dizem exatamente o contrário do que aparentam dizer.

A arte se antecipa, em muito, à nossa própria compreensão acerca do quotidiano e suas nuances políticas. Em manifesto político, Lefebvre (1991, p. 7) afirma que o teatro moderno "somente pode ser um lugar onde a vida cotidiana alcança seu mais alto grau de intensidade; onde as palavras e gestos da vida cotidiana finalmente assumem um sentido" (tradução nossa). Buscando referências junto ao dramaturgo alemão Bertold Brecht, Lefebvre (1991, p.14) recupera o que seria a recorrência entre a vida cotidiana e o teatro, defendendo "um teatro em que a ação (e poesia) seria expressa e deliberadamente trazida para perto da vida cotidiana" (tradução nossa).

É preciso entender, sobretudo, que o teatro é uma prática cuja ocorrência não se restringe a uma apresentação realizada em um palco. Segundo Carlos (2007, p. 54), Lefebvre apreende o cotidiano que flui pelas ruas da cidade, enquanto espaço público de passagens e conexões, e no interior das quais acontecem os encontros, trata-se de um "teatro espontâneo", onde cada um pode ocupar o papel de ator e/ou de espectador.

O teatro que se desdobra continuamente na vida cotidiana, embora apresente um aspecto fictício, traz à tona papeis sociais reais, exigindo uma ruptura com visões padronizadas e opiniões inflexíveis, convidando o ator/atriz a representar a realidade do/a outro/a, no momento de encenação. Pode-se entender essa vivência como uma aproximação à alteridade, e a encarnação de diversos papeis sociais pode causar fortes impactos no ator/atriz. 


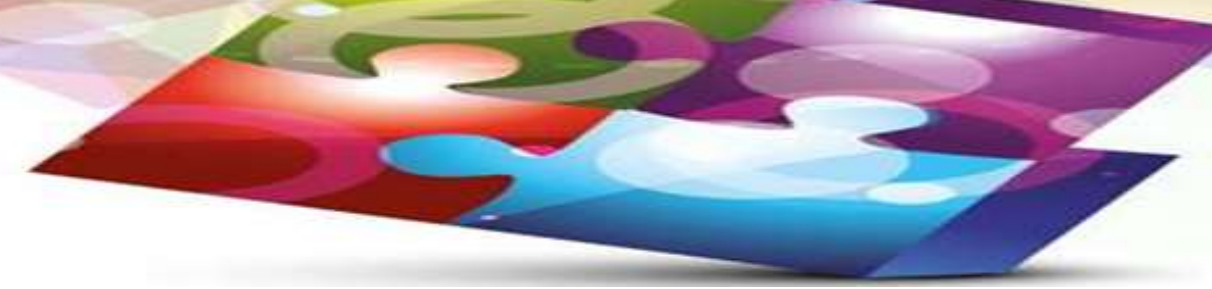

Os atores e as atrizes são diversificados/as e possuem suas particularidades. Por isso, falar sobre o teatro e sobre a corporeidade das pessoas envolvidas nesta trama, não é uma tarefa simples, quando damos conta dessas diferenças. Um exemplo pertinente, são o perfil e a linha estudados pelo ator. Embora ele/a seja qualificado/a para atuar em diversas modalidades, há de se considerar que suas crenças, culturas e meios em que vivem exercem significativa influência - enquanto são produzidas por ele/a. Um ator ou uma atriz residente em uma cidade pequena possui características que os diferem de um ator ou atriz da cidade grande, e assim sucessivamente. Porém, “[...] não se deve esquecer que o artista, o cientista, o estadista, não vivem constantemente nessa tensão. Possuem também, como todos os outros homens, uma vida cotidiana; o particular-individual manifesta-se neles, tal como nos demais homens" (HELLER, 2008, p. 29). Conforme aponta a autora, as vivências cotidianas do/a artista enquanto um ser humano comum, como qualquer outro, constitui um fenômeno presente e inegável. Portanto, a partir desse pensamento, devemos considerar tudo o que ele/ela constrói nesse dia a dia como extensões dele/dela próprio e que, portanto, estabelecem uma relação de forte influência em todos/as os/as outros setores de sua vida, inclusive, a atuação, ainda que esta apresente um/a outro/a "ser", diferente do próprio ator/atriz.

$\mathrm{O}$ artigo está dividido em duas seções. A princípio, nos propomos a discutir sobre o teatro enquanto prática que possibilita a abertura ao pensamento, trazendo, com isso, a percepção da alteridade. Quando avançamos no sentido de nos libertarmos das gaiolas conceituais em que nos aprisionaram, isso predispõe ao encontro com a diferença e com o outro. Dialogicamente, a segunda seção é dedicada à relação entre o artista e o público, compreendendo que a arte se faz no interior desta relação. Estas discussões pretendem contribuir para com os estudos em cotidianos, as pesquisas em ciências humanas e as práticas de ensino, sobretudo se as tomarmos enquanto metáforas que possibilitam conexões com o outro.

\section{O teatro nosso de cada dia}




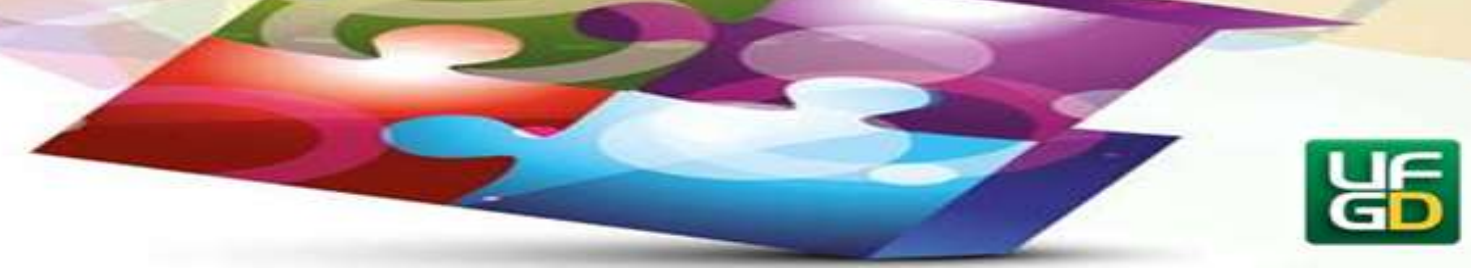

Ser ator está além de um registro emitido pela Delegacia Regional do Trabalho (DRT), independe se você é profissional ou não - aliás, qual seria o sentido desta palavra, "profissional"? Seria quem vive e se sustenta com a arte? Ou quem frequentou cursos, estudou grandes nomes e teóricos importantes na história do teatro? Ou é quem ama, quem vive o teatro dia a dia? Não nos cabe definir, o teatro tampouco precisa de uma definição, de um significado, ele fala por si só, não precisa de grandes apresentações. A vivência teatral pressupõe deslocamentos em ambiências complexas e contraditórias, e algo semelhante acontece na vida cotidiana.

Quando nos interessamos pela arte, passamos a olhar e a enxergar o mundo em suas conexões; o mínimo gesto se revela acontecimento em um grande palco. De maneira simplificada, poderíamos dizer que olhamos para "detalhes" que raramente interessam à grande maioria, gestos que passam despercebidos àqueles que sucumbem aos direcionamentos hegemônicos. O/a ator/atriz inscreve sua vivência como se ela ocorresse em um "laboratório"; grande parte do tempo ele/ela estuda e observa o outro, o jeito como fala, a maneira que pisca os olhos, como segura o copo, um cigarro, se o sorriso é de canto ou com a cabeça flexionada para trás. Tudo passa a ser notado, e algumas situações levam a pensar: "Isso daria uma cena". A postura do ator e da atriz é bastante semelhante à dos/as estudiosos/as do cotidiano no que se refere a esta "atenção densa" direcionada aos detalhes da vida e às suas sutis diferenciações. Para o pesquisador, a observação cotidiana costuma resultar em "Isso daria um texto".

No teatro, ao se deparar com a necessidade de interpretar uma condição social marginalizada ou sobre a qual o próprio ator/atriz já construiu conceitos antecipados, a ideia de alteridade precisa ser permanentemente revisitada. Aqui, é importante ressaltar que a alteridade não se restringe à aceitação do/a outro/a, pois que ela atua em algo mais amplo. Para Henri Lefebvre (1991), a alienação não ocorre meramente no plano econômico - ou seja, não são apenas as condições de produção que produzem e mantêm uma perspectiva alienada - mas também na incapacidade de pensar o/a outro/a. Para ele/ela, portanto, a consciência seria a

\footnotetext{
${ }^{5}$ A adjetivação endereçada a este tipo de atenção guarda alguma similaridade com as proposições de Geertz (1989) ao tratar da "descrição densa" nos estudos etnográficos. A descrição densa produz, em seu registro e caracterização da realidade, um grande esforço no sentido de se aproximar dos sentidos produzidos pelo outro.
} 


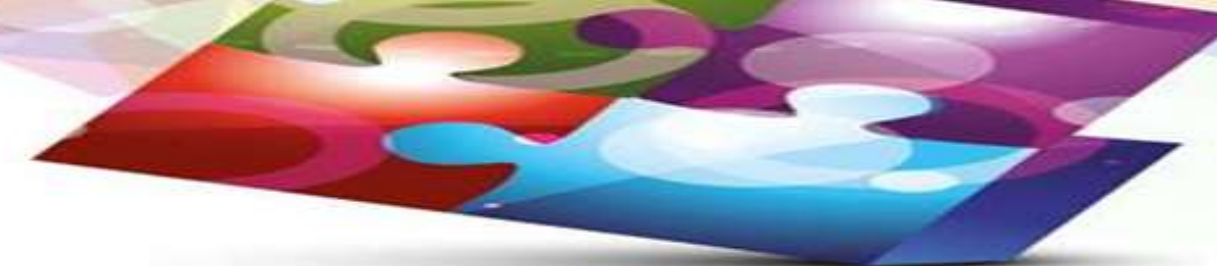

consciência dos modos de existência do/a outro/a. Na relação com o/a outro/a, o trabalho de conscientização acerca das lógicas, linguagens e práticas deste outro/a seria o que nos distanciaria de uma vida alienada. Usualmente tomada enquanto justificativa para a rejeição e a guerra, a diferença do/a outro/a, se abordada pela consciência, seria o plano imensurável no qual se desdobrariam, contraditoriamente, a liberdade e a paz.

Por vezes, influenciados/as por determinadas construções que fazemos em relação aos comportamentos do/a outro/a, esquecemo-nos de que as supostas diferenças são, na verdade, traços da grande complexidade que o constitui. De acordo com Skliar (2006, p. 22), “A 'différance' não é uma distinção, uma essência, ou uma oposição, mas um movimento, uma referência à alteridade, a uma heterogeneidade que não é, em princípio, oposicional. As diferenças são, isso sim, diferenças políticas e, portanto, diferenças de oposição.”

As características de um indivíduo que o diferem de outro/a fazem parte de sua existência enquanto outro/a, e eis aí o grande desafio do ator e da atriz: compreender esse aspecto e, ainda assim, ser o outro/a no momento da atuação, rechaçando as ideias construídas sem o conhecimento da causa, e entendendo-as como parte da figura que ele ou ela representa naquele momento.

Nas pesquisas em educação e ensino, a percepção do/a outro/a é também fundamental. Muito facilmente o capturamos de forma a conhecer como observa o mundo - sem notar que o observar do/a outro/a, muitas vezes, é deformado/a pelo nosso, para nós. O que diz, o que faz, o que sente - costumamos ler quase tudo através de nossos pressupostos. Esta seria uma interface na qual os/as pesquisadores/as em cotidianos e os/as atores/atrizes teatrais se encontram: como compreender o/a outro/a, sem reduzi-lo/a a uma cópia de mim? Como preservar quem sou e, simultaneamente, entregar-me aos sentidos produzidos pelo/a outro/a?

É certo que estas indagações conduzem a uma discussão de séculos, referente às ideias de neutralidade e objetividade. Em seu livro, no qual indaga acerca da paisagem e da posição do/a pesquisador/a no "mirante", Löwy (1998), destaca um grupo de quatro positivistas que trataram destas questões durante o período que inaugurou a primeira revolução científica (Século XVI), e durante o Iluminismo. O primeiro deles, o francês Augusto Comte (17981857), estabeleceu, com sua "física social", que os fatos sociais deveriam ser observados de 


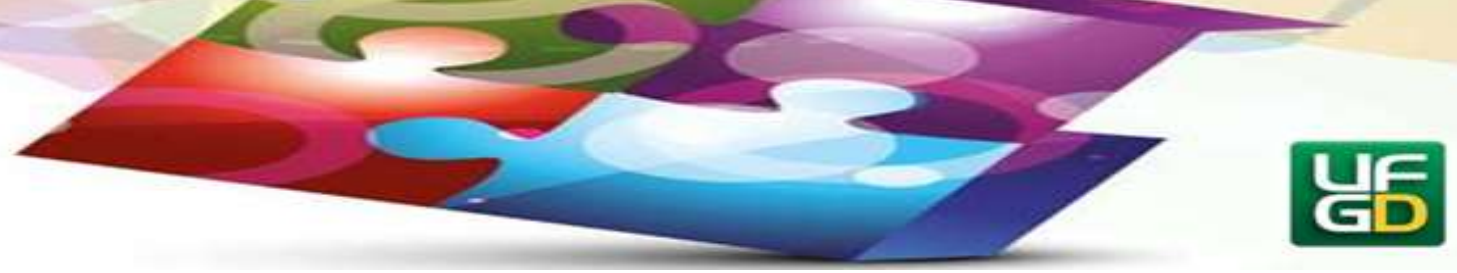

forma neutra e rigorosamente objetiva, alimentando a ideologia da ordem burguesa. $\mathrm{Na}$ Alemanha, Max Weber (1864-1920) arriscou afirmar a existência da subjetividade, mas a negou ao defender que esta pode ser controlada pela objetividade. Enquanto isso, o contemporâneo de Weber, Emile Durkheim (1858-1917), trabalhava, na França, com os primórdios da Sociologia. Em seus estudos, convertia o referencial metodológico proveniente das ciências naturais, e os aplicava aos estudos da sociedade. Para ele, uma sociedade deveria ser estudada a partir da organização estatística do todo, ignorando as subjetividades individuais. Posteriormente, o austríaco Karl Popper (1902-1994) refuta a objetividade, mas garante que ela é possível quando fizer parte de um esforço coletivo. Ou seja: se muitas pessoas estivessem convencidas do rigor cientificista aplicado a determinado experimento, a objetividade estaria garantida. Ah, caro Barão de Münchhausen ${ }^{6}$, o senhor insiste em sair do pântano puxando a si mesmo pelos cabelos?

Seja na prática teatral, na prática científica ou na prática da vida cotidiana, estamos sempre em relação com o/a outro/a. Nossa herança positivista, por vezes, orienta esta relação, tornando o outro menor, de forma a governá-lo melhor. A arrogância desta "razão indolente" (SANTOS, 1987) impera sem grandes dificuldades, pois a relação entre os diferentes é passível de ser conduzida segundo os princípios da subalternização (LEFEBVRE, 1991a). Veja: se "existir é diferir", como afirmou, no Século XIX, Gabriel Tarde (2003), todas as relações humanas serão encontros com a diferença. Jamais teremos, como interlocutores, um igual. A diferença nos constitui, e, passados quase quatrocentos anos das primeiras lições provenientes do cientificismo, o positivismo ainda se infiltra e media as relações humanas. Infelizmente, não é possível apagar em nós os traços herdados da ciência moderna - seria como utilizar o esquizofrênico positivismo, para apagar a si mesmo. E é Heisenberg (1987) quem nos diz desta triste realidade: não podemos esquecer as concepções modernas que nos impelem a observar, classificar, mensurar, hierarquizar; não há uma rota de fuga que nos liberte deste pensamento,

\footnotetext{
${ }^{6} \mathrm{O}$ chiste é uma referência honrosa ao livro de Löwy, o qual trabalha com a metáfora do cavaleiro que afirmava ter saído de um pântano puxando a si mesmo (e a seu cavalo), pelos cabelos. Esta metáfora implica na resolução de uma dificuldade por uma via improvável.
} 


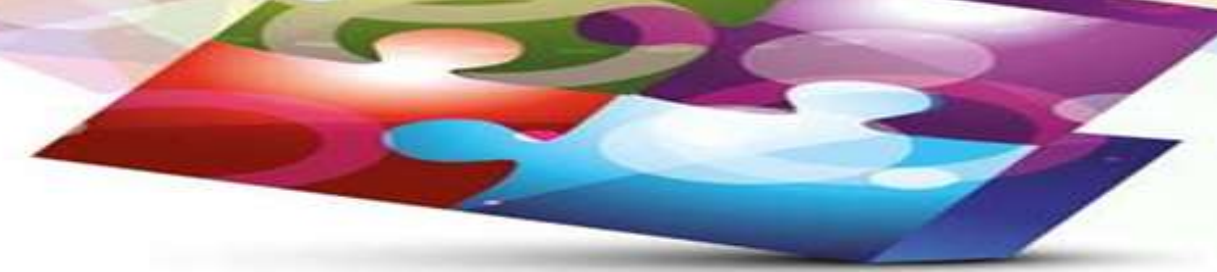

pois a herança não pode ser devolvida. O que resta, então, aos/às praticantes do teatro, da atividade científica e da vida cotidiana?

Esta tem sido uma questão recorrente para muitos estudiosos, há séculos, e não é nossa pretensão julgá-la inaugural ou tentar uma resposta. Trata-se de uma questão que se desdobra ao infinito, e que aborda a relação com o outro - uma relação que imperiosamente conduz ao governo do outro, mas que lutamos para que possamos preservar o que há em mim, e o que há em você. A preservação da diferença, em meio a uma relação que se processa, implica em um trabalho permanente desde o qual travamos embates com as influências positivistas, as lógicas colonialistas (SANTOS, 2007), os juízos de valor ativados enquanto preconceitos e todo um "arsenal" que reduz o outro que vem ao nosso encontro. Não há solução para este dilema, mas a resistência que acontece enquanto se pensa permanentemente sobre isto, é algo que desenha epistemologicamente possibilidades para uma vivência decente com o outro.

No palco, um artista representa quem não é. Na pesquisa, um/a pesquisador/a estabelece conversações com quem não é. Na vida cotidiana, acontece de forma totalmente diferente, o mesmo. Aqui estou eu, ali está você. Eu olho para você e, a princípio, penso: eu vejo você. Por instantes esqueço de notar que você também olha para mim. E que você, como eu, também pensa. Por instantes, esforço-me por colonizar ${ }^{7}$ você. Eu me sobreponho, eu capturo você. Ah, esta herança... Mas estou vigilante. Respiro fundo, olho novamente para você. Você, assim como eu, somos "sistemas estruturalmente fechados" (MATURANA, 1997), o que significa que nossa organização (o que temos em comum) é permanente, e nossa estrutura (o que há de singular), é variável. O que nos afeta, individualmente, pode advir do outro, mas é sempre aquele que recebe, quem determina como será afetado, já que as mudanças são "desencadeadas pelo agente perturbador, mas determinadas pela estrutura do sistema perturbado" (MATURANA \& VARELA, 1995, p. 131).

Pensar sobre "sistemas estruturalmente fechados" propostos por Humberto Maturana (1997) é algo que alimenta a resistência. Se meu encontro com você é mediado pela

\footnotetext{
${ }^{7}$ Todas as referências à colonização presentes neste artigo são afiliadas ao pensamento de Boaventura de Souza Santos e dizem respeito às práticas de tomada e apropriação do outro. As entradas desta colonização ocorrem através da cultura, linguagem, corporeidade, religiosidade, gênero e tantas outras frentes identitárias que são frontalmente atacadas pelo colonizador.
} 


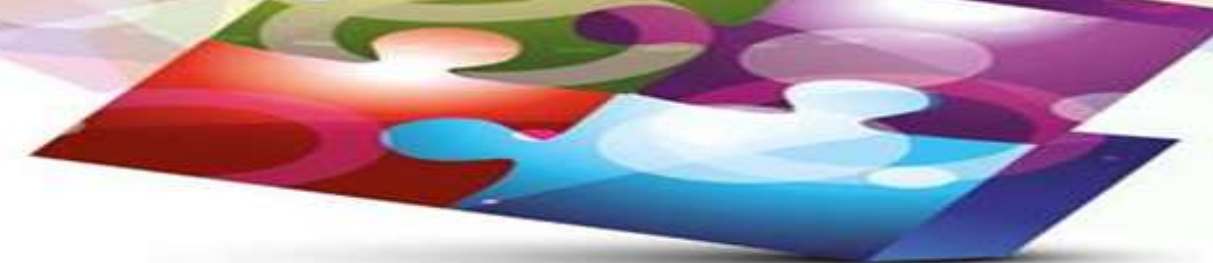

compreensão de que aquilo que te ofereço e aquilo que você me oferece é determinado por você, isso redimensiona estes ímpetos que sinto por te colonizar. Você se afigura, para mim, enquanto um ser completo, pleno, que me instiga, que me atrai em sua diferença, e com quem eu posso aprender. É isso: representar o outro na cena teatral ou na atividade científica, seria um encontro admirável e respeitoso com a inteireza imensurável da diferença.

Assim, tanto o outro que habita nossa atividade científica, como também a arte, são capazes de nos tocar, de fazer jorrar nossas emoções e de redimensionar nossas percepções, provocando deslocamentos que envolvem, sempre, a apreciação do outro. Este encontro com o outro, quando desprovido de intencionalidades colonizadoras, é potencialmente marcado por aprendizagens e amorosidade - porque libertador, libertário e livre.

\section{Entre o artista e o público, a arte}

A observação de uma cena teatral ou de uma cena cotidiana geralmente nos remete a uma das polaridades resultantes desta mesma observação: depositamos nosso olhar sobre o/a artista ou sobre o público; depositamos nosso olhar sobre um interlocutor, ou sobre o outro. Este gesto cartesiano fragmenta a cena e neutraliza justamente o que poderia nos dizer algo, uma vez que, observando as polaridades, ficamos parcialmente cegos ao que se passa na relação, ao que acontece, às entonações presentes.

A observação das polaridades talvez seja uma recusa à deriva do que há no contexto. Temos aprendido, há mais de quatrocentos anos, que "O mundo é complicado e a mente humana não o pode compreender completamente. Conhecer significa dividir e classificar para depois poder determinar relações sistemáticas entre o que se separou" (SANTOS, 1987, p. 5). O artista que observa seu público e o/a pesquisador/a que observa os sujeitos da pesquisa são, facilmente, aprisionados nesta armadilha. Olhar, nomear, controlar, determinar - são ações que tomam o outro como objeto, convertendo o público em mercado consumidor, e os sujeitos da pesquisa em informantes. Teatro e vida cotidiana, neste momento, se coisificam; todo o universo de sentidos tecidos no interior das relações, são ofuscadas. 


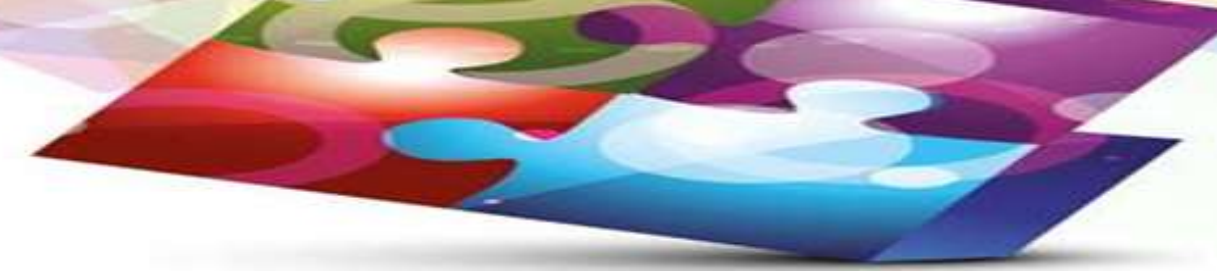

Desta forma, ao observarmos apenas um ponto ou outro, não nos deixamos abrir para a complexidade que tece uma cena teatral ou cotidiana; tampouco, percebemos as raízes que se entrelaçam em tal momento, porquanto nossa percepção está trabalhando segundo o modelo arbóreo (DELEUZE \& GUATARRI, 1995). Não importa o quão algo pode ser aproveitável, se, visto sob essa ótica, está fadado à limitação das partes, as quais poderiam estar sendo amplamente observadas, de modo a formar um todo movente, que não apresenta ponto de partida, nem de chegada. Na prática, uma das consequências de não considerar a cena teatral como rizomática (DELEUZE \& GUATARRI, 1995), poderia ser a desarmonia entre a arte e o cotidiano. E, assim, o espectador se sentiria diante, meramente, de um espetáculo artístico, em detrimento do movimento e representação da vida.

Retomando a Charles Chaplin, temos um interessante exemplo de como a relação entre público e artista se dava rizomaticamente, sem que os limites que supostamente distinguiriam cenas cotidianas e teatrais, fossem traçados. Trata-se de um ator que, ainda que se esteja falando em termos de cinema, possuía o encantamento responsável por fazer com que a linha que separa vida e arte se apagasse.

Por meio deste encontro entre o público e a atuação de Chaplin, podemos perceber que a representação, através de sua fluidez e naturalidade, apresenta conexões com a vida cotidiana. O palhaço Chaplin não precisou se esforçar, e tampouco fez uso de uma grande produção para que as pessoas se vissem nos movimentos que ele empreendia. Ele foi capaz de perturbar os espectadores, desamarrando as raízes do pensamento. O resultado, para quem o assiste, é ser tomado por uma emoção, naquele momento. Esta emoção acende uma outra possibilidade, tecendo reflexões que as histórias de Chaplin, embora cômicas e leves, podem suscitar; visto que, em suas obras, é possível notar um forte comprometimento com questões sociais. Mais uma vez tem-se a metáfora do rizoma bem representada, pois, nas películas de Charles Chaplin, não há delimitações quanto ao início e término das dimensões artísticas, cotidianas, sociais ou culturais, de modo que não há como afirmar qual delas se sobrepõe, enquanto as demais se mostrariam sutilmente. 


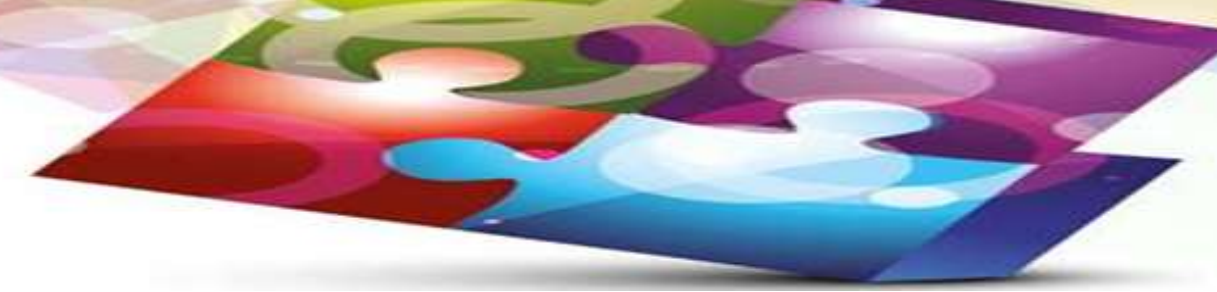

Para Henri Lefebvre (1991), Chaplin se aproxima ingenuamente de um universo sofisticado de pessoas e coisas que preservam comportamentos fixos, um universo no qual as pessoas se comportam como coisas e em conjunção com coisas:

Ao se deparar com os acontecimentos da vida cotidiana, Chaplin se percebe em dificuldades e se adapta. As dificuldades então se mostram de novo e ele vence uma série de situações tensas, durante as quais vemos momentos de relaxamento seguidos de altas tensões. Com a simplicidade de uma criança, Chaplin entra em batalhas com objetos cotidianos: um guarda-chuva, uma cadeira, uma motocicleta, sempre deleitado com a estranheza e riqueza das coisas, sempre tornadas embaraçosas por práticas ritualizadas. Chaplin captura nossa própria atitude em direção às coisas triviais, e diante de nossos olhos. Ele se tona um estranho em um mundo familiar e de repente nos desorienta, mas somente para nos mostrar o que somos quando enfrentamos objetos; e estes objetos se tornam repentinamente estranhos, o familiar não é mais familiar. Neste desvio através da desorientação e do estranhamento, Chaplin nos reconcilia com o mais alto nível, com nós mesmos, com as coisas e com o mundo humanizado das coisas (LEFEBVRE, 1991, p. 10 - tradução nossa).

Tanto o/a artista, quanto o/a pesquisador/a, devem se perguntar quais são os sentidos do exercício de sua profissão. Talvez muitos, inicialmente, se iludam a pensar que a grande tarefa do/a artista seja decorar os textos que encena, e o/a pesquisador/a, a seguir um roteiro estruturado. Mas, na prática, a realidade se transforma e apresenta tantos outros desafios, que nos levam a refletir. Eis que o/a artista é capaz de colocar seu corpo, sua alma e seus sentimentos à disposição de tantos personagens. Esse é um exercício difícil, posto que não é nada simples imaginar como o outro sente, como o outro pensa. O/a artista não só imagina e cria, é necessário sentir e acreditar naquilo que sente e pensa. Se não o faz, não convence aqueles que o observam. O/a artista precisa seduzir o/a espectador/a, envolvê-lo/a naturalmente, estar no palco e em cena livre, seguro. Então, realiza-se a conexão, e tudo começa a fazer sentido. Tudo flui.

Neste momento, o corpo do ator e da atriz se entrega ao fluxo de sentidos, porquanto é ele/ela quem se oferece para o público, abrindo-se às diversas sensações, que sinalizam, para ele/ela, seu próximo movimento, a intensidade do seu olhar ou a entonação da voz. Aqui acontece, na palavra e no gesto, toda a comunicabilidade do corpo humano. Disso, extrai-se a 


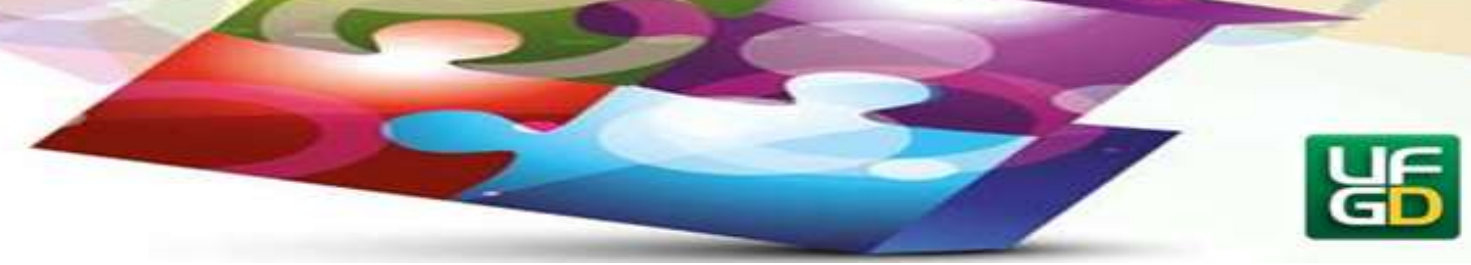

noção de conexão entre público e cena, que pode ser construída de acordo mesmo com a versatilidade do/a artista e sua habilidade em ser outros/as.

O/a pesquisador/a também precisa estar atento, para que haja interação com o que observa, para que flua e aconteça. Ambos/as precisam se envolver. Precisam crer para ver, e não o contrário. É uma conexão. Em outras palavras, a pesquisa seria como a vida, não linear. Capaz de despertar tantos outros caminhos, que até aquele/a que investiga poderá "surpreenderse" (LACERDA, 2015). Em suma, o/a pesquisador/a precisa estar atento a cada detalhe, ir além de uma observação superficial, estar disposto a olhar à sua volta com olhos de aprendiz, curioso e faminto. Assim como o ator e a atriz, que mesmo tendo o texto decorado, necessita praticar o difícil exercício de ouvir o/a outro/a, para que sua fala seja compartilhada, seja um diálogo e não um texto rebuscado, ensaiado e duro. É preciso ouvir o outro, como um outro. Quando conversamos com alguém, nós não adivinhamos o que será falado ou respondido; nós podemos imaginar, supor - mas ter certeza, não. No teatro, o ator e a atriz nunca estão sós, se não houver outro ator/atriz, ele/ela estará a contracenar com a quarta parede ${ }^{8}$, o respeitável público. Convém ressaltar, que o teatro é fisicamente formado por três paredes que compõe o palco: a parede traseira, que é a parede principal, e as paredes das laterais, direita e esquerda, que servem como base para inserir as "pernas" (estruturas feitas de tecidos ou outros materiais cenográficos) que servem para a fuga, quando o/a artista não fica mais visível no palco.

Pouco notada, neste cenário temos, ainda, a quarta parede, que é a ligação do público com os/as artistas. Se as paredes físicas oferecem suporte estrutural à cena, é na quarta parede que acontece a conexão necessária à arte. Tal descrição, aproxima-se de uma abordagem sobre o Teatro do Oprimido, criado pelo dramaturgo, diretor e teórico de teatro Augusto Boal. Nas palavras de Boal (2000, p. 13), “o Teatro do Oprimido é teatro na acepção mais arcaica da palavra: todos os seres humanos são atores, porque agem, e espectadores, porque observam. Somos todos espect-atores."

Sob tal complexidade, o Teatro do Oprimido relaciona-se diretamente com a expressão muito utilizada por artistas de teatro, que é a "quebra da quarta parede", organizada em

\footnotetext{
${ }^{8}$ A quarta parede é uma parede imaginária situada na frente do palco do teatro, através da qual a plateia assiste passiva à ação do mundo encenado.
} 
diferentes formas e técnicas, na qual a plateia se relaciona com a ação ocorrida no palco, transformando-se em uma plateia ativa, atuante, e assim transformadora da ação dramática encenada. Teatro é ação, "todo mundo atua, age, interpreta. Somos todos atores/as" (BOAL, 2000, p. 9). Dessa forma, os/as espectadores/as se tornam os/as principais protagonistas. Tudo que acontece é observado, sentido e tocado pelos artistas que realizam o Teatro Invisível (BOAL, 2000, p. 35) qual podemos associar com a prática do/a pesquisador/a, que também, observa, sente e descreve o que investiga em determinados campos de estudos - nos cotidianos das pessoas, que muitas vezes não os notam, ou não percebem que fazem parte desta ação.

Buscando aprender com as dimensões éticas do Teatro Invisível, entendemos que a prática investigativa adentra, respeitosa e humildemente, o universo do outro. Se há uma intenção de pesquisa, também há algo que a antecede: os sentidos postos pelo outro. Devido a isso, a pesquisa deve cuidar, permanentemente, das tensões presentes em uma agenda prescritiva, e do inusitado com o qual a realidade se apresenta.

Quanto a isso, Lefebvre (1991) estabelece distinção entre o teatro clássico e o épico, sendo que, enquanto o primeiro transcende a vida cotidiana e a purifica das "impurezas", o segundo mergulha nas massas de indivíduos, de temporalidades e práticas. $\mathrm{O}$ teatro clássico "purificador" seria aquele que apresenta uma história linear e contínua, desprovida de tensões e restrita a um enquadramento rigoroso, alimentado por "valores" das classes dominantes. Tudo isso produz a identificação entre o espectador e o herói, tornando mais eficaz a alienação e o repasse de normas e juízos de valor.

Para Lefebvre (1991), no teatro de Brecht, o encontro com as massas revelaria a ambiência de uma revolução democrática, apresentando a vida cotidiana sem a pretensão de purifica-la ou de ocultar suas contradições. Nesta proposição, o/a espectador/a é surpreendido/a ao se deparar com o que se passa, sem que a ele ou ela sejam oferecidos argumentos que possam alicerçar seu julgamento; diferente disso, seu julgamento está sempre em atraso em relação ao ato, e este ato não contribui em nada na definição deste julgamento. Este autor afirma que, na vida cotidiana, realizamos julgamentos que diferem daqueles proferidos por um juiz. Enquanto este conta com o estudo prévio de evidências e dispõe de tempo para se posicionar imparcialmente com o objetivo de aplicar uma lei, o sujeito da vida cotidiana aplica seu 


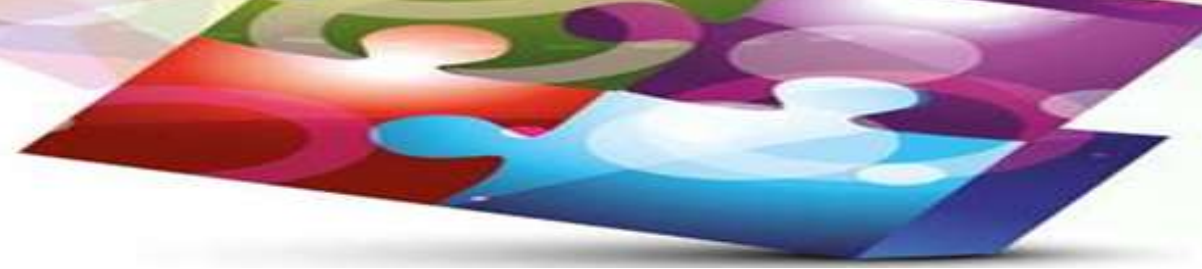

julgamento a situações imediatas: "a atitude do juiz exclui surpresas repentinas, espanto, expectativa" (LEFEBVRE, 1991, p. 24 - tradução nossa).

Para o/a espectador/a, a ação se desenrola como um todo que não pode ser fragmentado - embora cada parte contenha universos de sentidos. A relação do/a espectador/a com o que lhe é apresentado não é uma relação de consumo, pois o que se passa no palco, segundo Lefebvre (1991), acontece mais no interior de quem está assistindo, do que no palco propriamente dito. A cena teatral acontece dentro de você, e não no palco. Se algo acontece em você, e não somente externamente a você, “o espectador não pode relaxar. Isso não lhe é permitido. Ele deve tomar partido. Política, pública e contraditória, a peça teatral não é, fundamentalmente, diferente de um encontro" (LEFEBVRE, 1991, p. 22 - tradução nossa). Tomando a questão da alienação enquanto central em seu trabalho, Lefebvre (1991) afirma que o espectador tende a "desalienar" a si mesmo, pois seu destino é ser arrancado de si, para voltar a si, consciente da "real finalidade das contradições do real" (LEFEBVRE, 1991, p. 23 - tradução nossa).

Pois bem. Tomemos de empréstimo estas ideias de purificação, linearidade, acaso, política e outras, presentes na discussão lefebvriana. Tomemos estas ideias que ele traz ao verificar as similitudes entre a ação teatral e a vida cotidiana, de forma a pensarmos sobre nossas práticas de pesquisa, ou até mesmo sobre nossas práticas de ensino. Com isso, aprendemos que toda prática é política, como ensinou nosso mestre maior (FREIRE, 1987), e que sendo política, não pode ser, jamais, isenta de conflitos e contradições. Seja a ação teatral, seja a prática de pesquisa ou a prática de ensino - em qualquer prática habita a permanente tensão política que se processa continuamente, sem que haja continuidade. A cada ato, uma nova tensão, um novo problema, o desvelamento de uma contradição; a cada ato, a emergência por compreender e agir, sem que o ato nos ofereça elementos que possam orientar nossos julgamentos, ou tempo para que possamos refletir demoradamente. Tanto a vida cotidiana, quanto o teatro, quanto as práticas em geral, acontecem em resposta ao inusitado.

Vejamos uma cena cotidiana, e nela, seus “atores/atrizes". Habitantes de uma mesma conversa, por algum tempo permaneceram falando, juntos, sobre a mesma coisa. Havia, contudo, algo que diferia: os sentidos. Tratando do mesmo, trilhavam caminhos diferentes - o que quase encerrou a conversa em uma lógica hegemônica: 


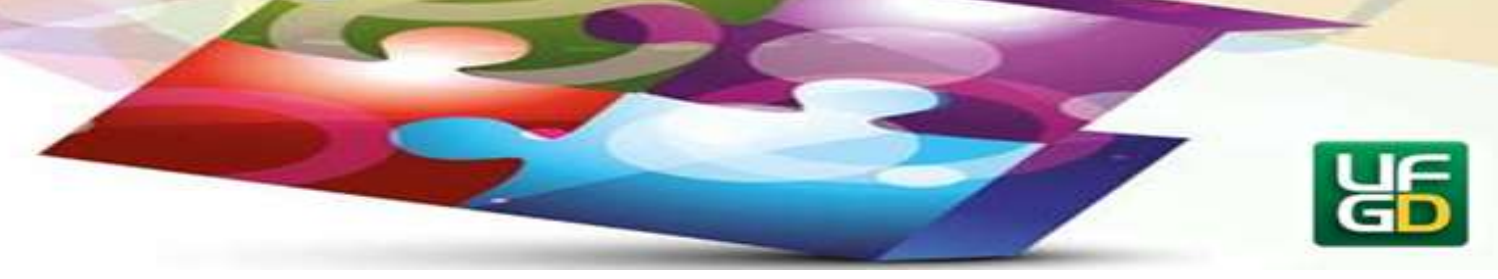

Recém-chegada à roça, ela olhava com olhos suficientes de quem já viu tudo. Queria saber sobre a produção, sobre o manejo, sobre o cultivo e tudo o mais. Não tardou a verificar que a água da bica era escassa, e perguntou pela nascente. Ele falava pouco, ou, pelo menos, era assim que ela traduzia a densidade do que ele dizia. Então ele contou que a nascente ficava naquele morro, nas terras de alguém, e que aquela água abastecia dezesseis famílias, mas que estava secando. O dono da terra estava plantando café, e, com isso, desmatando e batendo o pasto em direção à nascente. Ela ouviu e imediatamente se pôs a oferecer uma explicação, pois trazia, consigo, um discurso prontinho acerca da preservação da água, e não demorou a elencar o que deveria ser feito para reverter a situação. Discurso correto, científico, carregado de procedimentos a serem efetuados. Ele ouviu o que ela disse, e calou. O silêncio se instalou visivelmente, mas, interiormente, ela desconfiou e se entregou a compreender. Quando as normatizações cessaram nela, ele disse que as pessoas do lugar conversavam sobre a questão da água, de casa em casa, de boca em boca, conforme se configurava uma ocasião, e que o assunto cresceria até o momento bom de se fazer a coisa certa. Não se tratava, portanto, de ir até o dono da terra ensinar "o padre nosso ao vigário": a coisa era complexa, e uma resposta simples, não seria suficiente para resolver a questão. Ela ouviu, e olhou para o chão: havia, ali, uma muda de hortelã. Mais adiante, outra. E outra. E outras tantas. Mas, note: não eram várias plantas; era a mesma. Sua raiz se ramificava por baixo da terra sem se deixar ver, e ela brotava em diversos lugares, sem que se pudesse precisar onde, ou quando (DIÁRIO DE CAMPO, Julho/2016) ${ }^{9}$.

Este fragmento recupera, dentre outras coisas, a ideia de alteridade e o repensar a respeito do protagonismo na cena. Não há sentido em encenar quando a intenção é capturar, colonizar; não há sentido em conversar, quando o objetivo é submeter o outro aos nossos pressupostos. Santos (2007) tem discutido a respeito de um pensamento abissal, fruto de uma arrogância epistemológica, a qual define a hegemonia de um determinado saber. Ele o nomeia enquanto "razão indolente", sendo que é possível encontrá-la nas mais diversas práticas sociais. A razão indolente é aquela que produz a inexistência do outro, sobrepondo-se às diferentes lógicas desde as quais as pessoas tecem a vida. Ela é perceptível nas ações empreendidas pelos dominantes, mas também adentra algumas práticas aparentemente providas do sentimento do bem comum. Assim, "tudo aquilo que é produzido como inexistente é excluído de forma radical

\footnotetext{
${ }^{9} \mathrm{O}$ relato foi reproduzido desde o diário de campo de uma das autoras e é parte de pesquisa sobre a sociabilidade no campo (em desenvolvimento).
} 


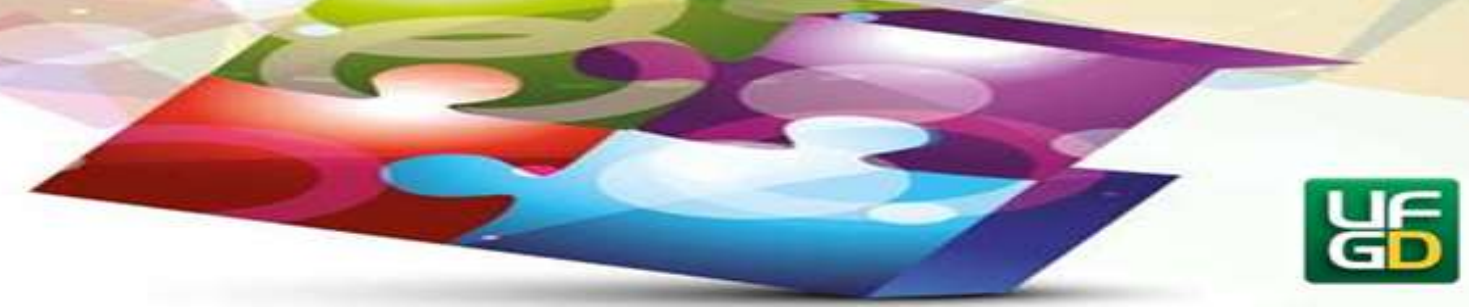

porque permanece exterior ao universo que a própria concepção de inclusão considera como o outro" (SANTOS, 2007, p. 71).

Com a delimitação das linhas abissais (SANTOS, 2007), o outro é reduzido e deformado: não é ouvido, não é visto, e suas lógicas são convertidas em ignorância. Ao saber da possibilidade de destruição da nascente, ela definiu, temporariamente, sua escuta: as palavras que escutava, foram traduzidas enquanto conformismo. Porém, quando conseguiu suspender a razão indolente que a orientava, conseguiu ouvir com ouvidos de alteridade, e as mesmas palavras passaram a sinalizar o posicionamento crítico de quem vivia aquela realidade.

Portanto, não é incumbida somente ao artista a tarefa de se desdobrar, independentemente de suas construções enraizadas. Nós, enquanto seres sociais e cotidianos, também estamos sujeitos a diferentes momentos que nos transformam em diferentes figuras, consoante nossa posição. Essas classificações ultrapassam os limites agora imagináveis, visto que o ser humano constitui-se de uma grande complexidade, em constante construção. Muitas vezes, assim como no palco, precisamos escolher entre transitar por diferentes papeis sem considerar nossos preconceitos, ou sujeita-los à nossa vigilância epistemológica.

\section{Conclusões}

As reflexões acerca de práticas teatrais aqui apresentadas assemelham-se com a vida cotidiana nos mais diversos aspectos. A partir da conversação realizada no decorrer deste trabalho e das reflexões tecidas acerca das práticas investigativas e didáticas que perpassam exercícios teatrais nos palcos e nos cotidianos, podemos nos aproximar de uma percepção mais latente da realidade em que vivemos. Levando-se em consideração esses aspectos, observamos que o teatro se desdobra e se renova cotidianamente. O/a artista/a se faz no outro - um outro, e assim traz à tona papeis sociais, uma representação do que eu sou, do que você é ou do que nós poderíamos ser. Observamos que o pesquisador estabelece relações com um outro em suas 


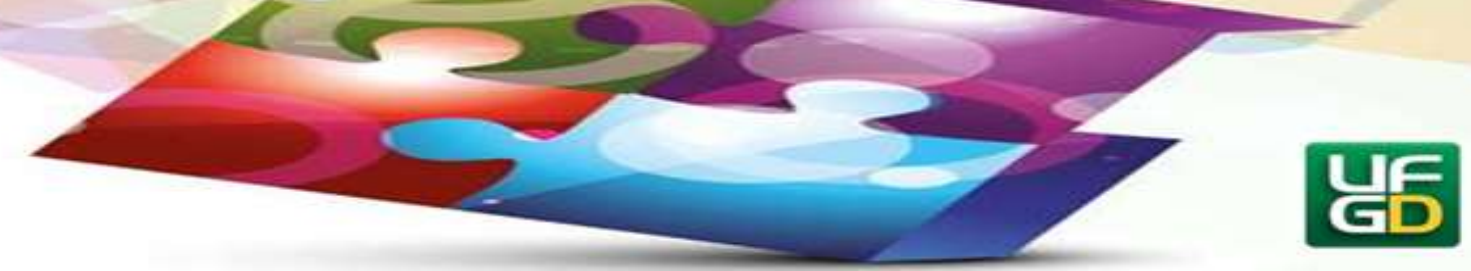

investigações e que o mesmo nos acontece. Entendemos que seja na prática teatral, na prática científica ou na prática da vida cotidiana, estamos sempre em relação com o outro - e que seria a consciência da existência do outro o que nos libertaria de uma vida alienada (LEFEBVRE, 1991).

Observamos que o teatro apresenta inúmeras imagens da vida cotidiana, as quais não são isentas de ideologias. É válido salientar que no comportamento teatral o ator não pode alienar-se, por mais seguro que esteja sobre o seu papel. $\mathrm{O}$ ator e a atriz imitam a vida, retratam o que é real, seja qual for o cenário e a forma como o mesmo é denominado perante a obra. Definimos assim, que o teatro é uma arte atrevida, visto que mostra sem pudor, o que teimamos em ocultar no cenário real, onde por diversas vezes, somos nós os protagonistas. A reflexão sobre o exercício artístico teve, neste ensaio, a intenção de se pensar algumas tramas didáticopedagógicas presentes no cenário da educação. Se o pensamento moderno dividiu, classificou e isolou cada fragmento da realidade, nossa resistência opera livremente no pensar. Junto ao desejo por conectar percepções acerca de práticas distintas - arte e ciência -, temos trabalhado no sentido de compreender que os retalhos que constituem o conhecimento, na atualidade, podem se colocar em movimento, em patchworks vivos, sempre outros.

Sendo assim, tanto na prática teatral, na prática científica ou na prática da vida cotidiana, a responsabilidade com o outro é fundamental, porque pertencemos a um mundo relacional, que se desdobra em um palco. Deste modo, entendemos que o palco se mostra enquanto um espaço de discussão, reflexão e tensão permanente que, fictício ou real, aborda problemas tecidos e vivenciados pela sociedade. Assim, acreditamos que a criação textual, a interpretação e a representação de diferentes papeis, produzem discursos que conectam universos humanos os quais nos cabe, humildemente, conhecer.

\section{Referências}

BOAL, Augusto. Jogos para atores e não-atores. Rio de Janeiro: Civilização Brasileira, 2000.

CARLOS, Ana Fani Alessandri. O lugar no/do mundo. São Paulo: FFLCH, 2007.

CERTEAU, Michel de. A invenção do cotidiano. Petrópolis: Vozes, 2014. 


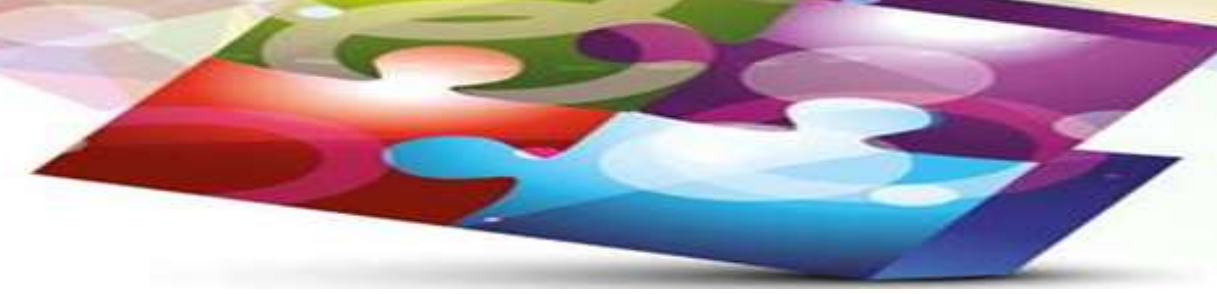

DELEUZE, Gilles; GUATTARI, Félix. Introdução: Rizoma. In: Mil Platôs.

Capitalismo e Esquizofrenia. Rio de Janeiro: Ed.34, 1995.

GEERTZ, Clifford. A interpretação das culturas. Rio de Janeiro: Guanabara: 1989.

FREIRE, Paulo. Pedagogia do Oprimido. Rio de Janeiro: Paz e Terra, 1987.

HEISENBERG, Werner. Física e filosofia. Brasília: Editora UnB, 1987.

HELLER, Agnes. O Cotidiano e a História. São Paulo: Paz e Terra S/A, 2008.

LACERDA, Mitsi Pinheiro de. Em práticas pedagógicas e investigativas... a surpresa. Revista Entreideias, Salvador, V. 4, N. 1, p. 7-22 jan./jun. 2015.

LEFEBVRE, Henri. Critique of Everyday Life. London: Verso, 1991.

LEFEBVRE, Henri. A vida cotidiana no mundo moderno. São Paulo: Ática, 1991a.

LÖWY, Michael. As Aventuras de Karl Marx contra o Barão de Münchhausen. Marxismo e Positivismo na Sociologia do Conhecimento. São Paulo: Cortez, 1998.

MATURANA, Humberto. A ontologia da realidade. Belo Horizonte: Ed. UFMG, 1997.

MATURANA, Humberto, VARELA, Francisco. A árvore do conhecimento. Campinas: Editorial Psy, 1995.

SANTOS, Boaventura de Sousa. Um discurso sobre as ciências. Porto, Portugal: Afrontamento, 1987.

SANTOS, Boaventura de Sousa. Para além do pensamento abissal. Das linhas globais a uma ecologia de saberes. Novos estudos - CEBRAP. 2007, n. 79, pp. 71-94.

SKLIAR, Carlos. A inclusão que é "nossa" e a diferença que é do "outro." In. RODRIGUES, Davi (org). Inclusão e educação: doze olhares sobre a educação inclusiva. São Paulo: Summus Editorial, 2006, pp. 16-34.

TARDE, Gabriel. Monadologia e Sociologia. Petrópolis: Vozes, 2003. 